\title{
Signature of explosive volcanic eruptions in the sediments of a high-altitude Swiss lake
}

\author{
Alex Blass · Martin Grosjean • \\ David M. Livingstone $\cdot$ Michael Sturm
}

Received: 12 October 2006/ Accepted: 24 January 2007/Published online: 6 April 2007

(C) Springer Science+Business Media B.V. 2007

\begin{abstract}
The analysis of 125 years of well-dated varved sediments in Lake Silvaplana, located at $1,791 \mathrm{~m}$ a.s.l. in the Upper Engadine region of south-eastern Switzerland, reveals that 7 out of the 8 climatically relevant explosive volcanic eruptions between A.D. 1880 and 2004 were followed by distinct peaks in median grain-size. Although the underlying mechanisms are yet unclear, an analysis of local meteorological data suggests that this phenomenon is unlikely to be related to any change in air temperature associated with the eruptions, but instead may be related to an increase in autumn precipitation subsequent to the eruptions that led to the erosion and fluvial transport of particles larger than normal.
\end{abstract}

\section{A. Blass $(\bowtie)$ \\ D. M. Livingstone · M. Sturm}

Swiss Federal Institute of Aquatic Science

and Technology (EAWAG), Ueberlandstrasse 133,

8600 Dübendorf, Switzerland

e-mail: alex.blass@eawag.ch

A. Blass · M. Grosjean

National Centre of Excellence in Research on Climate, University of Berne,

3012 Berne, Switzerland

M. Grosjean

Department of Physical Geography, University

of Berne, 3012 Berne, Switzerland
Keywords Volcanism - Eruption - Climate . Limnogeology · Sediment · Alps · Lake ·

Grain-size

\section{Introduction}

Not so long ago, the question of whether explosive volcanic eruptions had a perceptible effect on the surface climate of the earth was the subject of some controversy (Angell and Korshover 1985; Ellsaesser 1986), with considerable disagreement existing about the possible magnitude, spatial coverage and duration of any such effect. Since then, a number of studies have confirmed the importance of explosive volcanic eruptions for the global climate (e.g. Bradley 1988; Sear et al. 1987; Shindell et al. 2004). The mechanism by which such eruptions influence the climate involves the injection of large quantities of sulphurous gases into the lower stratosphere, where they are rapidly dispersed globally and undergo photochemical conversion to sulphate aerosols (Castleman et al. 1974). The resulting increase in the backscattering of solar radiation leads to significant surface cooling on global scales (e.g. Bradley 1988; Robock and Mao 1995; Sear et al. 1987).

Less attention has been paid to the local climatic effects of explosive volcanic eruptions, partly because it can be difficult to detect a clear 
volcanic signal in individual instrumental data series due to masking by local processes (Pisek and Brázdil 2006). Nevertheless, the signature of volcanic eruptions has been detected in local tree ring series (e.g. Briffa et al. 1998) and also in the ice phenology of some Northern Hemisphere lakes (Livingstone 1997, 2000). In particular, the calendar date of ice break-up on Lake St. Moritz, a high-altitude lake in south-eastern Switzerland, appears to respond sensitively to volcanic forcing (Livingstone 1997).

Here, we address the question of whether a volcanic signal is traceable in the sediments of Lake Silvaplana, situated $5 \mathrm{~km}$ to the south-west of Lake St. Moritz. We compare 125 years (A.D. 1880-2004) of well-dated, annually laminated sediments from this lake (Blass et al. 2007; Leemann and Niessen 1994; Ohlendorf et al. 1997) with climatically relevant volcanic eruptions that occurred during the same period, and with local instrumental meteorological data.

\section{Study site}

Lake Silvaplana $\left(46^{\circ} 27^{\prime} \mathrm{N}, 9^{\circ} 48^{\prime} \mathrm{E}\right)$ is located at an altitude of $1,791 \mathrm{~m}$ a.s.l. in the Upper Engadine region of south-eastern Switzerland. The lake has a maximum depth of $77 \mathrm{~m}$ and a volume of $127 \times 10^{6} \mathrm{~m}^{3}$ (LIMNEX 1994), and is icecovered from January to May. It has a catchment area of $129 \mathrm{~km}^{2}$, of which about $6 \mathrm{~km}^{2}(\sim 5 \%)$ was glaciated in 1998 (Blass et al. 2007). The most important inflow, the Fedacla River, with a mean discharge of $1.5 \mathrm{~m}^{3} \mathrm{~s}^{-1}$, is fed mainly by glacial meltwater and carries a high load of suspended particles.

Compared to the Swiss Plateau, the climate of the Upper Engadine is more continental in character. The amplitudes of the diurnal and annual air temperature cycles exceed those typical of the Swiss Plateau, and it is comparatively dry, with an annual mean precipitation (19611990) of $978 \mathrm{~mm}$ year $^{-1}$ (SMA 2002). Thunderstorms are relatively infrequent (20 days year ${ }^{-1}$, SMA 2002). The area lies in a meteorological boundary zone and receives precipitation from all wind directions, but most frequently from the south (Brunetti et al. 2006). The weather divide is often situated close to the lake. Based on data from the IPCC reference period (1961-1990), monthly mean air temperatures range from $-7.2^{\circ} \mathrm{C}$ in January to $10.4^{\circ} \mathrm{C}$ in July, and monthly mean precipitation from $42 \mathrm{~mm}$ in February to $121 \mathrm{~mm}$ in August (average 1961-1990, SMA 2002).

\section{Methods and data}

A sediment core $85 \mathrm{~cm}$ long was recovered in winter 2004/2005 using a freeze-coring technique (Kulbe and Niederreiter 2003), which perfectly preserved the annual (varved) layering of the sediment. Varve counting was carried out using digital core photographs and thin sections, and was independently verified with ${ }^{137} \mathrm{Cs}$ dates (Blass et al. 2007). The chronology of the last 125 years was found to be in good agreement with a completely independent varve count conducted by Ohlendorf et al. (1997). The comparison of (i) the total annual mass accumulation rates with summer air temperatures (Blass et al. 2007) and (ii) biogenic silica flux with autumn air temperatures (Blass et al. submitted) suggests that dating is accurate to within \pm 3 year during the last 125 years. The study period was therefore defined as A.D. 1880-2004.

Every single varve was individually sampled in a freeze laboratory $\left(-10^{\circ} \mathrm{C}\right)$. Sub-samples were freeze-dried. In order to separate the siliciclastic fraction from the bulk sediment, organic matter and biogenic silica were removed using $\mathrm{H}_{2} \mathrm{O}_{2}$ and $\mathrm{NaOH}$, respectively. Grain-sizes were subsequently measured with a Malvern Mastersizer Hydro 2000S. The standard deviation of the median for multiple measured samples was always $<0.5 \mu \mathrm{m}$.

Layers that were interpreted as mass-flow deposits with a thickness exceeding $1 \mathrm{~mm}$ were excluded from the record. Five values in the 1960s were discarded due to contamination with overlying coarse-grained flood deposits. Annual layers were not visible in the freeze-core from 12 to $18 \mathrm{~cm}$ (1954-1977) because of very low mass accumulation rates and high proportions of 
organic material. This short sequence had to be supplemented with parallel data from a gravity core taken at the same position to develop a continuous chronology. As sediment samples were only taken from the freeze core and not from the short core, samples are not strictly annual in this $6 \mathrm{~cm}$ long section, but instead were sampled at regular depth intervals of $3 \mathrm{~mm}$, which corresponds approximately to 1 year.

Many volcanic eruptions were observed during the study period (Simkin and Siebert 1994), but only a few of these are likely to have been climatically relevant. We considered an eruption to be climatically relevant if it satisfied two different criteria based (i) on the Volcanic Explosivity Index (VEI) of Newhall and Self (1982), updated by Simkin and Siebert (1994), and (ii) on the Volcanic Aerosol Index (VAI) of Robertson et al. (2001). The first criterion, also used by Livingstone (1997, 2000), was that the $\mathrm{VEI} \geq 4$, implying that the eruption definitely resulted in the injection of material into the stratosphere (Newhall and Self 1982). However, because the VEI is based on physical evidence alone (volume of ejecta, column height, duration of eruption etc.), it is not a reliable measure of the amount of sulphur dioxide injected into the stratosphere. To take this into account, the second criterion employed was that the $\mathrm{VAI} \geq 0.025$ at $48^{\circ} \mathrm{N}$ (Robertson et al. 2001). The latitude-dependent VAI, which is a measure of the optical depth of the volcanic aerosol, is based on a combination of documentary evidence, ice core data from Greenland and
Antarctica, and recent satellite data. Eight major volcanic eruptions that occurred during the study period satisfied both criteria (Table 1).

A superposed epoch analysis (Conrad and Pollak 1962) was conducted following the methodologies adopted for example by Livingstone (2000). The year of each eruption was defined as year zero. For each variable to be analysed, mean values over all eight eruptions were calculated for each of the 5 years immediately before and immediately after year zero, allowing the mean effect of an eruption to be determined by comparing post-eruption with pre-eruption years. The superposition averages out unwanted noise, thus resulting in a relative enhancement of any signal that might have been left by the volcanic eruptions in the variable concerned.

During the entire study period (1880-2004), local meteorological data were measured at the Sils-Maria meteorological station, $1 \mathrm{~km}$ from the lake shore, which began operations in 1864. In this study, data on air temperature and precipitation from this station were utilised.

\section{Results}

A comparison of our annually resolved sediment record with the times of occurrence of the eight selected eruptions showed that seven of the eight eruptions were followed by a distinct peak in median grain size in comparison to the background decadal mean value (Fig. 1). The exception was the eruption of Agung in 1963, which was not followed by a detectable peak. The peaks

Table 1 List of climatically relevant explosive volcanic eruptions during the period A.D. 1880-2004 that satisfy both the criteria VEI $\geq 4$ (Newhall and Self 1982; Simkin and Siebert 1994) and VAI $\geq 0.025$ (Robertson et al. 2001)

\begin{tabular}{llllrl}
\hline Year A.D. & Month & Volcano & Location & VEI \\
\hline 1883 & August & Krakatau & Indonesia & 6 & 0.09 \\
1902 & May & Pelée & West Indies & 4 & 0.05 \\
& May & Soufrière & West Indies & 4 & 0.05 \\
& October & Santa Maria & Guatemala & 6 & 6 \\
912 & June & Novarupta & Alaska & 4 & 0.05 \\
1943 & February & Paricutin & Mexico & 4 & 0.10 \\
1951 & January & Lamington & New Guinea & 5 & 0.09 \\
1963 & March & Agung & Indonesia & 0.03 \\
1982 & April & El Chichón & Mexico & 5 & 0.06 \\
1991 & June & Pinatubo & Philippines & 6 & 0.12 \\
\hline
\end{tabular}




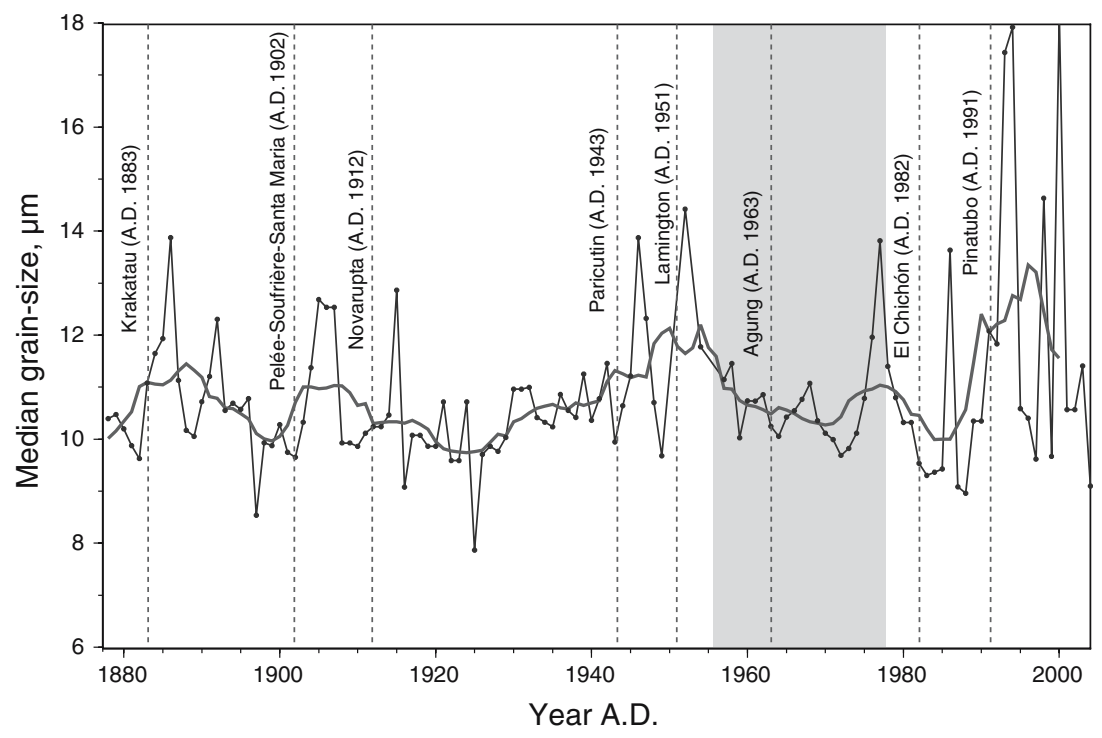

Fig. 1 Comparison of the occurrence of anomalous peaks in the median grain-size of varved sediments of Lake Silvaplana with the occurrence of climatically relevant explosive volcanic eruptions. The curves represent the annual median grain-size (thin line) and the corresponding 9-year running mean (thick line). The vertical dashed lines show the years of occurrence of the eight explosive volcanic eruptions selected. The shaded area highlights

occurred 1-4 varve years after each eruption (which is within the chronological dating error), and their magnitudes varied from $1.5 \mu \mathrm{m}$ (PeléeSoufrière-Santa Maria in 1902) to $5 \mu \mathrm{m}$ (Pinatubo in 1991). Superposed epoch analysis of the grainsize data reveals a distinct peak 3 years after each of the eruptions (Fig. 2). The distribution of the grain-size values 3 years after an eruption differs significantly from that 3 years before an eruption (two-tailed $t$-test, $t=3.3, P<0.01$ ).

\section{Discussion}

It is now accepted that explosive volcanic eruptions have a detectable influence on global climate (e.g. Jones et al. 2004; Robock and Mao 1995; Sear et al. 1987). Specifically, Fischer et al. (2007) suggest a weak post-eruption influence on summer precipitation over the European Alpine area. Although the influence of explosive volcanic eruptions on individual meteorological data series may be masked to part of the sediment sequence that was not sampled annually, but for which the resolution was close to annual. Five values in the 1960 s were discarded due to contamination with coarse-grained flood deposits. The standard deviation of the median grain-size, based on multiple determinations of the median grain-size for 5 representative varves, was always less than $0.5 \mu \mathrm{m}$

some extent by local processes (Pisek and Brázdil 2006), detection is likely to be easier at high altitudes, where cloud cover and anthropogenic emissions have less of an effect on climate than at lower altitudes. Explosive volcanic eruptions with a $\mathrm{VEI} \geq 4$ do indeed appear to influence at least one important aspect of the behaviour of high-altitude Alpine lakes, viz. ice phenology (Livingstone 1997), whereas lower-lying lakes are much less affected (Livingstone 2000). The mechanisms by which explosive volcanic eruptions might affect lakes are not yet clear; nevertheless, two potentially plausible hypotheses can be put forward to explain the observations illustrated in Figs. 1 and 2. First, post-eruption cooling would cause significant changes within glaciated catchments, causing changes in grain-size by affecting ablation rates. Second, a post-eruption increase in the amount or intensity of precipitation would increase the kinetic energy of rivers and erosion rates, resulting in an increase in median grain-size. Additionally, in both cases 
Fig. 2 Superposed epoch analysis of the median grain-size of the sediments of Lake Silvaplana with respect to the 8 climatically relevant explosive volcanic eruptions listed in Table 1. The error bars represent one standard deviation

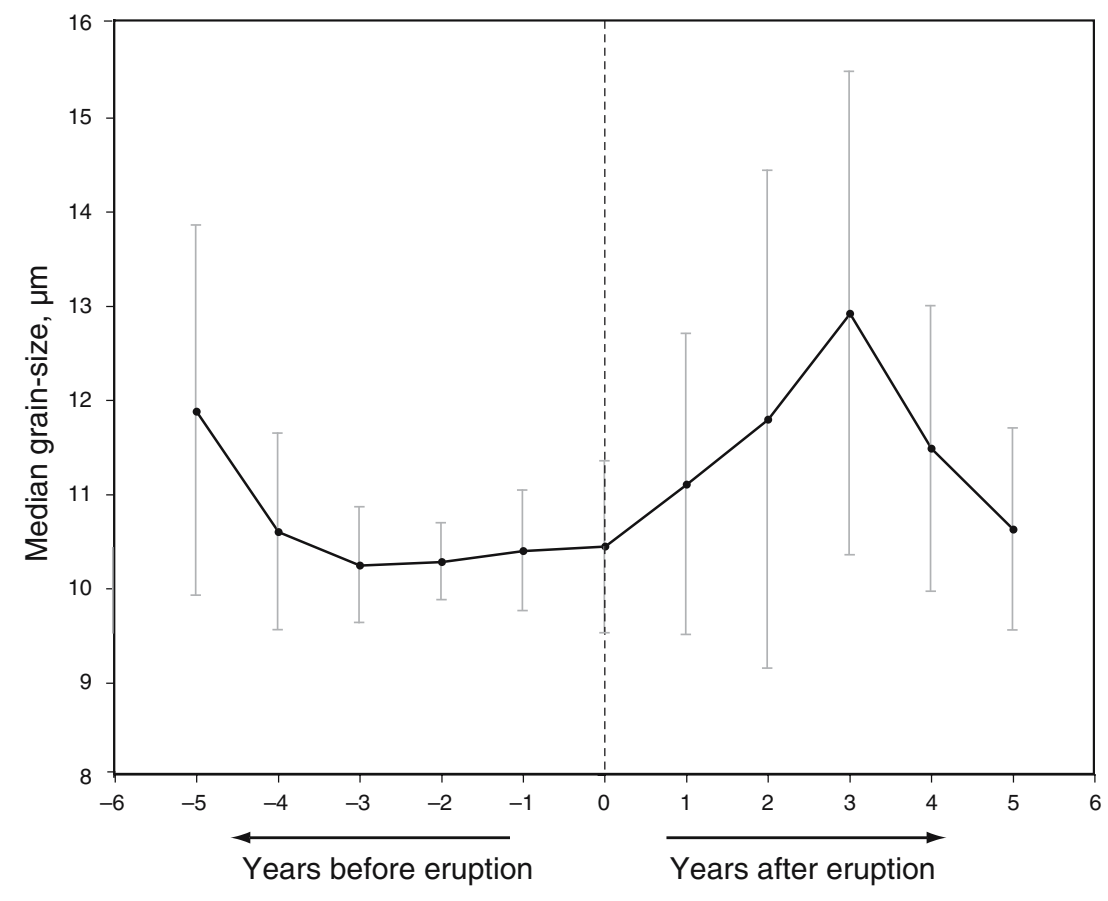

the relative importance of the various sources of sediment particles (glacial abrasion with predominantly physical weathering versus soil erosion with mixed physical and chemical weathering) would be altered, which would also affect the median grain size.

The first hypothesis was tested by applying a superposed epoch analysis to detect whether the eight selected volcanic eruptions had any influence on the local air temperature series at SilsMaria during the study period. No significant $(P>0.05)$ influence of the eruptions was found on annual mean air temperatures, seasonal temperatures or monthly mean temperatures, regardless of whether these were calculated based on daily means, daily minima or daily maxima. This finding agrees with the results of the impact study of Fischer et al. (2007), who were able to detect summer cooling following 15 major volcanic eruptions that occurred since A.D. 1500 in northern and north-eastern Europe, but not in the more southerly region of Europe in which Lake Silvaplana is located.

The second hypothesis was tested by analysing the instrumental precipitation time series at SilsMaria for each of the eight eruptions separately.
Figure 3 shows the precipitation anomalies calculated with respect to each 5-year pre-eruption period. The variability of the monthly precipitation anomalies was found to have increased after an eruption. The $95 \%$ confidence interval of the monthly precipitation anomaly underwent an increase after 6 of the 8 eruptions, and the number of extremes (defined as the number of months lying outside the $95 \%$ confidence interval) increased from 8 prior to an eruption to 17 afterwards (Table 2). From Table 2 it is evident that most of the extremes represent unusually wet conditions in autumn, which, for the reasons given above, would result in an increase in the median grain-size of particles transported from the catchment to the lake. Thus, while there is no evidence to support the first hypothesis, the second hypothesis can be viewed as plausible, although the processes involved are at the moment poorly understood.

\section{Conclusions}

Our data show that, with a high degree of probability, large, climatically relevant, explosive 

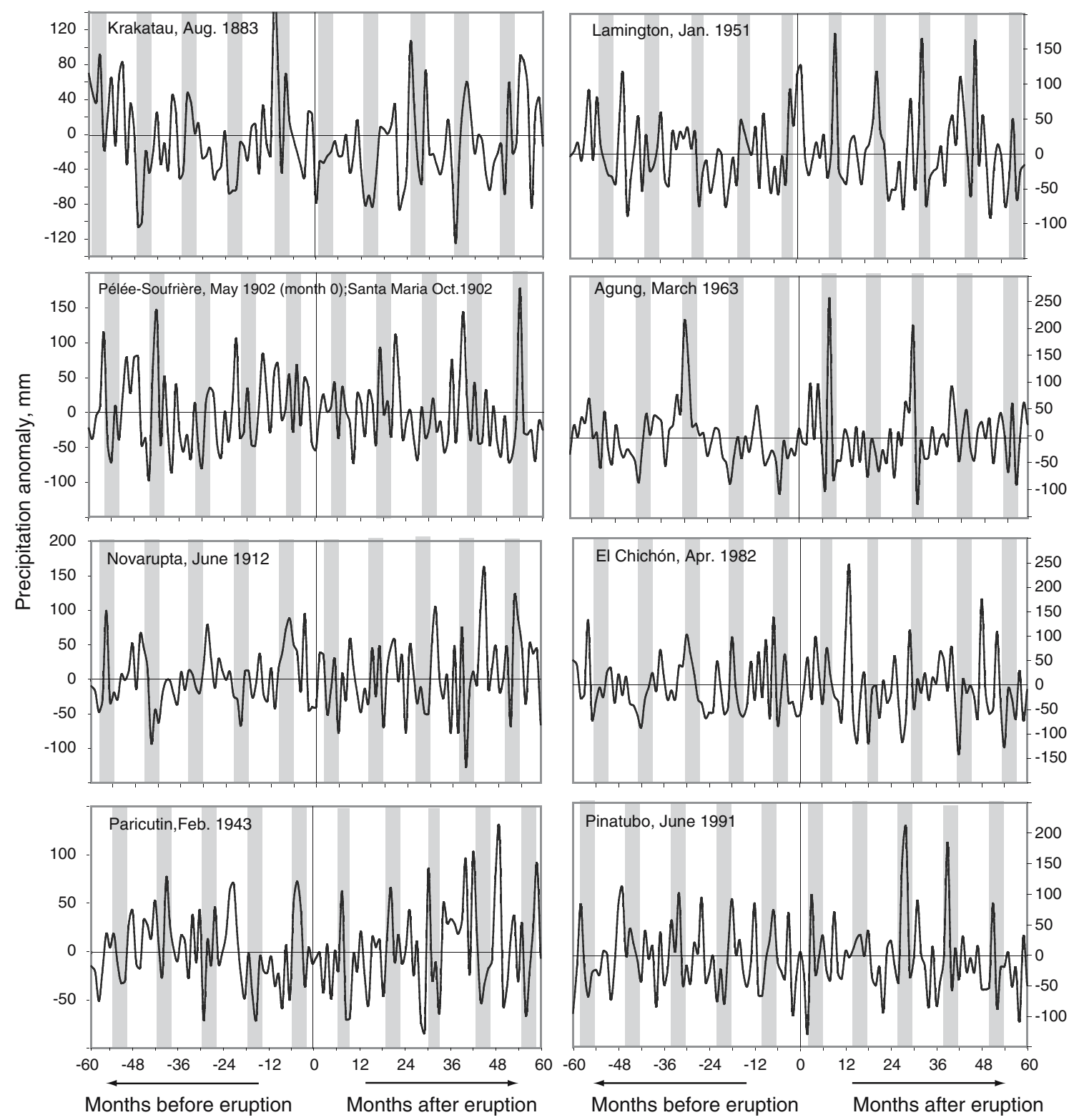

Fig. 3 Monthly mean precipitation anomalies at SilsMaria 60 months before and 60 months after each of the 8 climatically relevant explosive volcanic eruptions listed in Table 1. For each month, anomalies were calculated as

the departure from the relevant mean precipitation that occurred over the 60-month period prior to each eruption. Autumn months are shaded

Table 2 Monthly precipitation anomalies outside the $95 \%$ confidence interval in the 60 months before (in parentheses) and the 60 months after the explosive volcanic eruptions listed in Table 1 (see also Fig. 3)

\begin{tabular}{llllll}
\hline & Spring & Summer & Autumn & Winter & Year \\
\hline Unusually dry, $P<0.025$ & $(0), 0$ & $(0), 1$ & $(1), 0$ & $(0), 0$ & $(1), 1$ \\
Unusually wet, $P<0.025$ & $(1), 3$ & $(0), 1$ & $(5), 9$ & $(1), 3$ & $(7), 16$ \\
Total outliers, $P<0.05$ & $(1), 3$ & $(0), 2$ & $(6), 9$ & $(1), 3$ & $(8), 17$ \\
\hline
\end{tabular}


volcanic eruptions tend to be followed 1-4 years later by the increased deposition of larger than normal sediment particles in Lake Silvaplana. Although the mechanisms responsible for this are unclear at the moment, it would appear that the phenomenon is more likely to be the result of changes in the precipitation regime brought about by the eruptions than of any effect they may have on ambient air temperature. We conclude that the higher precipitation in autumn that follows explosive volcanic eruptions results in higher rates of erosion, and in the enhanced transport and deposition of large particles.

Acknowledgements We would like to thank Richard Niederreiter and Thomas Kulbe for their invaluable help with the freeze-corer during fieldwork. We are grateful to Stephan Margreth, Michael Strasser, Emmanuel Chapron, Alois Zwyssig, Erwin Grieder, Raphael Bühler and Brian Sinnet for their help in the field and in the laboratory. We also thank Jörg Leuenberger and Gerhard Furrer for allowing us to use the freeze laboratory at ETH Zurich. Christian Ohlendorf provided important information and valuable hints. Special thanks are due to Carlo Casty for his statistical and programming support. This research was funded by the Swiss National Science Foundation via NCCR Climate and the ENLARGE project (200021103892/1), the EUFP6 'Millenium' project, and by the Swiss Secretariat for Education and Science within the framework of the European Union Environment and Climate project Euro-limpacs (GOCE-CT-2003-505540).

\section{References}

Angell JK, Korshover J (1985) Surface temperature changes following the 6 major volcanic episodes between 1780 and 1980. J Clim Appl Meteorol 24:937951

Blass A, Bigler C, Grosjean M, Sturm M (submitted) Decadal autumn temperature reconstruction back to A.D. 1580 inferred from varved sediments of Lake Silvaplana (south-eastern Swiss Alps). Quat Res

Blass A, Grosjean M, Troxler A, Sturm M (2007) How stable are 20th century calibration models? A highresolution summer temperature reconstruction for the eastern Swiss Alps back to A.D. 1580 derived from proglacial varved sediments. The Holocene 17:51-63

Bradley RS (1988) The explosive volcanic eruption signal in northern hemisphere continental temperature records. Clim Change 12:221-243

Briffa KR, Jones PD, Schweingruber FH, Osborn TJ (1998) Influence of volcanic eruptions on Northern Hemisphere summer temperature over the past 600 years. Nature 393:450-455
Brunetti M, Maugeri M, Nanni T, Auer I, Böhm R, Schöner W (2006) Precipitation variability and changes in the greater Alpine region over the 1800-2003 period. J Geophys Res 111:D11107, doi:10.1029/ 2005JD006674

Castleman AWJ, Munkelwitz HR, Manowitz B (1974) Isotopic studies of the sulphur component of the stratospheric aerosol layer. Tellus 26:222-234

Conrad V, Pollak LW (1962) Methods in climatology. Harvard University Press, Cambridge, Massachusetts

Ellsaesser H (1986) Comments on "Surface temperature changes following the 6 major volcanic episodes between 1780 and 1980'. J Clim Appl Meteorol 25:1184-1185

Fischer E, Luterbacher J, Zorita E, Tett SFB, Casty C, Wanner H (2007) European climate response to tropical volcanic eruptions over the last half millennium. Geophys Res Lett 34:Doi:10.1029/2006 GL027992

Jones PD, Moberg A, Osborn TJ, Briffa KR (2004) Surface climate responses to explosive volcanic eruptions seen in long European temperature records and mid-to-high latitude tree-ring density around the Northern Hemisphere. In: Robock A, Oppenheimer C (eds) Volcanism and earth's atmosphere. AGU Geophysical Monograph, Washington, DC, pp 239-254

Kulbe T, Niederreiter R (2003) Freeze coring of soft surface sediments at a water depth of several hundred meters. J Paleolimnol 29:257-263

Leemann A, Niessen F (1994) Holocene glacial activity and climatic variations in the Swiss Alps: reconstructing a continuous record from proglacial lake sediments. Holocene 4:259-268

LIMNEX (1994) Gewässerzustand und Gewässerschutzmassnahmen im Oberengadin. Bericht zuhanden des Amtes für Umweltschutz, Kanton Graubünden, $75 \mathrm{pp}$

Livingstone DM (1997) Break-up dates of Alpine lakes as proxy data for local and regional mean surface air temperatures. Clim Change 37:407-439

Livingstone DM (2000) Large-scale climatic forcing detected in historical observations of lake ice break-up. Verh Internat Verein Limnol 27:2775-2783

Newhall CG, Self S (1982) The volcanic explosivity index (VEI) - an estimate of explosive magnitude for historical volcanism. J Geophys Res 87(C2):1231-1238

Ohlendorf C, Niessen F, Weissert H (1997) Glacial varve thickness and 127 years of instrumental climate data: a comparison. Clim Change 36:391-411

Pisek J, Brázdil R (2006) Responses of large volcanic eruptions in the instrumental an documentary climatic data over Central Europe. Int $\mathrm{J}$ Climatol 26:439-459

Robertson A, Overpeck J, Rind D, Mosley-Thompson E, Zielinski G, Lean J, Koch D, Penner J, Tegen I, Healy R (2001) Hypothesized climate forcing time series for the last 500 years. J Geophys Res 106(D14):1478314803 
Robock A, Mao JP (1995) The volcanic signal in surface temperature observations. J Climatol 8:1086-1103

Sear CB, Kelly PM, Jones PD, Goodess CM (1987) Global surface temperature responses to major volcanic eruptions. Nature 330:365-367

Shindell D, Schmidt G, Mann ME, Faluvegi G (2004) Dynamic winter climate response to large tropical volcanic eruptions since 1600. Geophys Res Lett 109:doi: 10.1029/2003JD004151

Simkin T, Siebert L (1994) Volcanoes of the world. Geoscience Press Inc., Tucson, Arizona, 349 pp

SMA (2002) Jahresbericht der Meteo Schweiz. Annalen der Meteo Schweiz, Band, p 139 